\title{
AUSTRALIAN INSTITUTE OF ABORIGINAL STUDIES MANUSCRIPT AND ARCHIVE COLLECTIONS
}

\author{
Brownlee Kirkpatrick
}

The Library has an extensive collection of manuscripts and archives comprising nearly 5000 accessions, many of which are either research workers reports and field notebooks or theses of which over 800 are held. Included in the Collections are a number of collected papers, diaries, correspondence and related material of individuals and collections on a single subject. As readers of Aboriginal History may be unaware of some of the material in this last category, the following is a list of the main collections as well as some important single items. Copies of material held elsewhere are also listed and, in the case of major collections, the archives holding the originals are noted at the end of the entry. The information noted is uneven as calendaring of collections did not commence until 1977; where detailed information is not yet available, the number of boxes is noted as a guide to the size of the collection. Access is restricted in some cases.

Abbie, Andrew Arthur, 1905-1976. Papers, manuscripts, letters, computer punch cards, offprints and related material on Aboriginal growth patterns, skinfold, dentition, blood groups and other aspects of human biology; the collection includes 332 offprints by various authors on human biology and archaeology of the Aborigines, and a large number of a general nature on similar subjects. 1615 items.

Barratt, Glyn R.V. collector. Materials relating to the early Russian visits to Port Jackson (1814-25), their ethnological significance, related material and translations from the Russian. 57 parts.

Bathurst Island Mission, NT. Genealogical data, c. 1950-67, compiled by Father J. Cosgrove. c. 400 cards.

Baudin, Nicolas, c. 1750-1803. Papers, manuscripts and drawings of his expedition of 1800-3. '6 reels (microfilm) (Archives Nationales, Paris and Musee d' Histoire Naturelle, Le Havre Collections).

Beagle Bay Mission. Nyol-Nyol language material, including French dictionary, Djawi vocabulary, notes on grammar kinship daily life, c. $1890-c .1930$. 1 box.

Brandl, Eric Joseph, 1923-1974. Papers, notes, maps and correspondence, including papers on Aboriginal rock art and sites of significance, 1958-74.c. 178 items and 276 letters.

Brierly, Sir Oswald Walters, 1817-1894. Journals on HMS Rattlesnake, 1848-50. (microfilm) (State Library, NSW).

Journal on HMS Rattlesnake and HMS Meander, 1849-51. (microfilm) (State Library, NSW).

Casey, Dermot Armstrong, 1897-1977. Papers, manuscripts and letters on prehistory and archaeology including excavation standards and surveying, anthropology, history, exploration, photography, offprints and related material. c. 285 items and $c .192$ letters.

Church Missionary Society, Roper River Mission Station. Correspondence on establishment of mission and securing of lease, 1908-67. 97 leaves.

Davies, Arthur Oliver Cromwell. Notes and papers on the Murray Islands, Torres Strait, including correspondence with A.C. Haddon, 1924-72. 20 items. 
Etheridge, Robert, 1847-1926. Manuscripts including notes on Aboriginal place names and ethnophytology, 1895-1920. 1 box.

Gardner, William. Production and resources of the northern and western districts of New South Wales, 1854. 2 vols. (microfilm) (State Library, NSW).

Gray, Frederick Harold. Material on Groote Eylandt Native Settlement and personal papers, including residence Iists, financial records, health data, linguistic notes, and notes on kinship, religion and art, 1927-60.c. I 84 items and 239 letters.

Gresser, John Percy. Manuscripts, notes and reminiscences on Aborigines and archaeology in the Bathurst District, personal correspondence, press clippings, photographs and related material, 1961-6. 1 box, 10 albums.

Gribble, Ernest Richard Bulmer, 1869-1957. Diaries, journals, correspondence and related material covering his work at the Yarrabah, Qld, Forrest River, WA and Palm Island, Qld, Missions, 1893-1952. c. 137 items (Australian Board of Mission Archives).

Gribble, John Brown, 1847-1893. Diaries, journals, correspondence and related material covering his work in Victoria, the Warangesda Mission, NSW, Western Australia and the Yarrabah Mission, Qld. 1873-92. c. 1062 leaves (Australian Board of Mission Archives).

Hale, Kenneth L. Alyawara, Aranda, Gunwinjgu, Gurindji, Kaititj, Lardil, Northern Pamá, Walbiri, Warramunga, Yanjula linguistic field notes, 1959-60. 6451 leaves.

Hamilton Aborigines Uplift Society, Victoria. Correspondence 1938-46 and minute books, 1938-57. 1 box.

Herbert, Sidney Wellington. Reminiscences of life in the Northern Territory during the construction of the overland telegraph, August 1870 to November 1872 . 245 p. (microfilm) (State Library, SA).

Howitt, Alfred William, 1830-1908. Papers, c. 1873-1907. 52 folders (National Museum of Victoria Collection).

Illidge, Thomas, 1843-1927. Manuscripts including word lists (one by Tom Petrie) from the Gayndah area, Qld, 1870-1908. 1 box.

Jagg, F.C. and William I. Kennett. Reports and correspondence on the Mission to the Aborigines at Somerset, Qld, 1866-8. 1 box.

Jericho, Helen. Papers, reminiscences, correspondence and newspaper clippings of the Kopperamanna district, South Australia, early 1900s. 2 boxes.

Kaberry, Phyllis Mary, 1910-1977. Field notebooks and genealogies from the Kimberley region, May 1934-May 1936. 27 vols.

Maclean, J.M., d. 1973. Notebooks, letters, maps and miscellaneous papers on New South Wales languages, mainly Kamilaroi and Wirnburi; inventory by $P$. Austin. 4 boxes.

MacPherson, John. Notes, correspondence, newspaper clippings and publications including material on the Ngarrabul and other tribes in New England, 18991939. 9 pts.

Mathew, John, 1849-1929. Papers, correspondence, offprints and related material on linguistics and religion including correspondence with E.H. Curr and W.E. Roth, a biography by his son, R.Y. Mathew and family correspondence. 266 items.

Mitchell River Mission, Qld. Register of baptisms, marriages and deaths, 1904-62. 24 leaves.

Mitchell, Stanley Robert, 1881-1963. Manuscripts on Aboriginal artefacts and letters, including correspondence with D.F. Thomson, c. 1930-63. 8 boxes. 
Moravian Mission in Australia. Papers, correspondence, transactions, diaries, and related material on the emigration to Australia (1832-50), first mission at Lake Boga and its abandonment (1849-57), beginning again in Gippsland (1858-70), correspondence associated with Lacepede Bay, Yorke Peninsula, Lake Condah, Kopperamanna, Coranderrk, Brisbane, Boorhooyanna (186589), Ebenezer and Ramahyuck (1858-1906), and North Queensland, Weipa, Aurukun and Mapoon (1885-1916). 26 parts, including 1786 letters (microfilm, 26 reels) (Archiv der Bruder-Unitat, Herrnhut, DDR).

Murray Island, Qld. Register of births, marriages and deaths, 1891-1928. 510 pages.

[Nekes, Hermann], Kimberley language material: D'aro, N'ol, etc., 1931-47. 7 parts.

O'Grady, Geoffrey Noel. Material on suffixing languages of Western Australia, including some comparative material from the Northern Territory and South Australia, 1957-8, and material on Njangumada, Julbaridja, Wanman and other West Australian languages, $c .1968 .601$ leaves.

Piddington, Ralph O'Reilly, 1906-1974. Port Hedland genealogies 1930-31. 6 notebooks.

Pink, Olive Muriel, 1884-1975. Papers, manuscripts, correspondence, pamphlets, circulars and press clippings on culture contact, living conditions of Aborigines and ethnographic material mainly on the Aranda and Warlpiri, with some Luridja, Arabanna and Pitjantjatjara; includes correspondence and reports on Hermannsburg, Finke River, Mt Margaret, Tennant Creek, Aurukun, Oenpelli and Bathurst Island Missions. 398 items and 780 letters.

Point Macleay and Point Pearce Reserves, SA. Register of births, marriages and deaths, 1857-1966. 120 leaves.

Purcell, Francis Xavier, collector. Documentation and supporting evidence in the case of Milirrpum and others v. Nabalco and the Commonwealth of Australia (Gove Land Rights Case), 1784-1972. c. 1011 items.

Radcliffe-Brown, Alfred Reginald, 1880-1955. Notebooks and vocabularies, 1910 1912 (WA) and 1926-1931 (NSW). 11 parts. (Department of Anthropology, University of Sydney).

Rechnitz, Wilhelm. Manuscripts relating to his missionary work in the Torres Strait Islands, 1956-66. 1 box.

Richmond River Historical Society. Miscellaneous records on Aborigines, including local legends and vocabularies, correspondence and press clippings, 18421963. 1 reel (microfilm).

Sharp, Richard Lauriston. North Queensland expeditions: field data, 1933-5, 1957. 11 parts.

Social Science Research Council of Australia. Aborigines Project directed by C.D. Rowley. Household surveys of New South Wales and South Australian families, research material and index, 1965. 7 filing cabinets and index cards (see C.D. Rowley's The Aboriginal householder, Quadrant, 1967, 50:90-6 and From humbug to politics: Aboriginal affairs and the Academy Project, Oceania, 1973, 43 (3): 182-97).

Somerset Settlement, Qld. Extracts from letter book no.1, 1871-81, includes letters to the Colonial Secretary, Brisbane from H.M. Chester, F.L. Jardine and C. Pennefather. 1 reel (microfilm) (State Library, NSW).

South Australia. Northern Territory - Administration. Office of Government Resident. Despatches and reports from Palmerston, NT, 1870-80. 9 parts. 
Spencer, Sir Walter Baldwin, 1860-1929. Papers and correspondence with Henry Balfour, F.J. Gillen, A.C. Haddon, W.E. Roth, E.B. Tylor and others, $c$. 1879-1927. (Pitt-Rivers Museum Collection, Oxford).

Stanrer, William Edward Hanley. Fitzmaurice River, NT field notes, sketch books; photographs and associated material, 1952, 1957-9, 1960. 13 parts.

Sweaman, John. Journal of a surveying voyage on HMS Bramble, 1842-7. 345 p. (microfilm) (State Library, NSW).

Thors son, Donald Fergusson, 1901-1970. Notebooks: Arnhem Land, June 1935Nov. 1936. 7 parts; and East Cape York Peninsula, 1928-1932. 17 parts. (National Museum of Victoria Collection).

Warren, Hubert Ernest de Mey and Mrs E.M. Warren. Diaries, notebooks and correspondence from the Roper River Mission, 1915-34. 8 parts.

Westlake, Ernest. Tasmanian notes, diaries and letters, 1908-10. 1 reel (microfilm). (Pitt-Rivers Museum Collection, Oxford).

Wilson, Robert $\mathrm{H}$. Diaries from Aurukun and Mornington Island, Qld, and from Kunmunya, WA, 1908-26. 6 parts.

AUSTRALIAN INSTITUTE OF ABORIGINAL STUDIES 